IZA DP No. 4577

Do Institutions Have a Greater Effect on Female Entrepreneurs?

Saul Estrin

Tomasz Mickiewicz

November 2009 


\title{
Do Institutions Have a Greater Effect on Female Entrepreneurs?
}

\author{
Saul Estrin \\ London School of Economics, \\ CEPR and IZA \\ Tomasz Mickiewicz \\ University College London
}

\section{Discussion Paper No. 4577 \\ November 2009}

\author{
IZA \\ P.O. Box 7240 \\ 53072 Bonn \\ Germany \\ Phone: +49-228-3894-0 \\ Fax: +49-228-3894-180 \\ E-mail: iza@iza.org
}

Any opinions expressed here are those of the author(s) and not those of IZA. Research published in this series may include views on policy, but the institute itself takes no institutional policy positions.

The Institute for the Study of Labor (IZA) in Bonn is a local and virtual international research center and a place of communication between science, politics and business. IZA is an independent nonprofit organization supported by Deutsche Post Foundation. The center is associated with the University of Bonn and offers a stimulating research environment through its international network, workshops and conferences, data service, project support, research visits and doctoral program. IZA engages in (i) original and internationally competitive research in all fields of labor economics, (ii) development of policy concepts, and (iii) dissemination of research results and concepts to the interested public.

IZA Discussion Papers often represent preliminary work and are circulated to encourage discussion. Citation of such a paper should account for its provisional character. A revised version may be available directly from the author. 
IZA Discussion Paper No. 4577

November 2009

\begin{abstract}

\section{Do Institutions Have a Greater Effect on Female Entrepreneurs?*}

This paper compares the impact of institutions on individual decisions to become entrepreneurs in the form of new business start ups by males and females across 44 developed and developing economies between 1998 and 2004. We test four hypotheses; that women are less likely to undertake entrepreneurial activity in countries where the rule of law is weaker; where the state sector is larger; where the informal financial sector is weaker and where the formal financial sector is weaker. We use data from the Global Enterprise Monitor survey (GEM) which covers at least 2,000 individuals annually in each of up to 44 countries, merged with country-level data, from the WB WDI and Heritage Foundation. We start with a spectrum of institutional variables and by utilizing factor analysis prior to regression estimation models, we are able to obtain results that are more robust and address multicollinearity between the institutional measures. We find that women are less likely to undertake entrepreneurial activity in countries where the state sector is larger, and demonstrate that this result applies to both high aspiration and low aspiration entrepreneurship. We also find that women benefit more from the larger informal financial sector.
\end{abstract}

JEL Classification: L26, J16, H11, O16, O17, P43

Keywords: female entrepreneurship, state sector, informal finance

Corresponding author:

Saul Estrin

Department of Management

London School of Economics

Houghton Street

London WC2A 2AE

United Kingdom

E-mail: s.estrin@lse.ac.uk

\footnotetext{
* The authors are indebted to Paul Reynolds for sharing the consolidated 1998-2004 GEM data. They would also like to extend their thanks to Stephen Hunt for his helpful assistance in navigating through the dataset. The paper has benefitted from comments by Harry Barkema, Susan Hill, Fei Qin, Virginie Perotin, Paul Reynolds, Ute Stephan and the participants of the World Bank and University of Michigan conference on Female Entrepreneurship. Any remaining errors are our own.
} 


\section{Introduction}

Early work on entrepreneurship (e.g. Schumpeter, 1934; Kirzner, 1973) implicitly assumed that most entrepreneurs would be men, perhaps because most business creation at that time was a male preserve. However, the situation has changed markedly, with women now owning more than $40 \%$ of the privately held firms in the US (Brush, 2006). The phenomenon of female entrepreneurship is also increasingly global, with a recent Global Entrepreneurship Monitor (GEM) study estimating that companies owned by women comprise between 25\% and 33\% of formal sector business around the world (Minniti, Arenius and Langowitz, 2005a). These developments have led to the emergence of a large literature on female entrepreneurship, analysing for example personal attributes, access to finance and the role of social networks (see Greene et al, 2003). While male and female entrepreneurs are similar in terms of motivation, age and education, significant differences have been identified. Of these, the most important for female entrepreneurs concern the sectors chosen for new firm creation (service and retail rather than manufacturing (Hisrich and Brush, 1984)); access to resources (some studies indicate less use of debt and greater difficulty in accumulating resources for start up (Verheul and Thurik, 2001)); and the use of less varied social networks (see Brush (2006) for a survey).

In this paper, we do not consider the similarities and differences between male and female entrepreneurs as restricted to a particular institutional context. Rather, we seek to explain the cross-country variation in male/female entrepreneurship rates. While there is a growing body of work at the country level related to gender dimension of entrepreneurship, surprisingly little has yet been attempted to enhance our understanding of the impact of 
alternative national business and cultural environments on women entrepreneurship ${ }^{1}$. We develop a number of hypotheses, with respect to property rights, the role of the state and functioning of financial markets, to explain how institutional variation might impact differently on male and female choices to become entrepreneurs. These are that women are less likely than men to undertake entrepreneurial activity in countries where the rule of law is weaker, where the state sector is larger, where the informal financial sector is weaker and where the formal financial sector is weaker. We go to test these hypotheses on a huge crosscountry individual data base, by comparing the impact of institutions on individual decisions about whether or not to become entrepreneurs in the form of new business start-ups by males and females.

Our analysis is made possible by access to the GEM database, which covers 44 developed and developing economies between 1998 and 2004 and which includes all startups regardless of the legal form. The Global Enterprise Monitor survey (GEM) covers at least 2,000 individuals annually in each of up to 44 countries. Our individual level data $(360,000$ usable observations) are generated through surveys creating stratified samples drawn from the whole working age population in each participating country. An empirical novelty of this paper lies in the merging of individual and country-specific institutional data, notably the Heritage Foundation indices and IMF data. Building on Aidis et al. (2009), we commence with a wide spectrum of institutional variables that allow for a comparative approach and by utilizing factor analysis prior to regression estimation models, we are able to obtain results that are more robust and address multicollinearity between the institutional measures. ${ }^{2}$ Our first cluster of institutional indicators is built around the rule of law / property rights, and the

\footnotetext{
${ }^{1}$ A little more has been done on the related theme of female employment. In particular, see Giavazzi et al. (2009), Algan and Cahuc (2007).

${ }^{2}$ We rely on the Heritage Foundation data in our econometric work because the principal factors method collapses when the World Bank Doing Business indicators are used instead.
} 
second around the size of the state sector. We also use data from the GEM survey and the World Bank WDI to indicate entrepreneurial access to informal and formal finance respectively.

Our equations control for the level of development and for business cycle as proxied by annual GDP growth rates. We find that, as hypothesised, while a smaller state sector positively affects entrepreneurship rates for all, the effect is significantly greater for females than for males. Similarly, access to informal finance has a positive significant effect on entrepreneurship generally, but a significantly greater one on females. However, contrary to our hypotheses, we are unable to discern a significant differential impact of formal credit availability and of rule of law on entrepreneurial activity for either gender. We consider reasons for these negative as well as the positive results, including non-linearities and the possibility that the impact of the rule of law is dependent on the stage of economic development. We interpret our findings in terms of gender specific incentives and opportunities within a typical household context, as augmented by alternative institutions.

There are several features of our study which are largely original. Existing studies focus either on self-employment, small enterprises requiring legal registration or on incorporated firms as a proxy for entrepreneurial activity. We are able to use data on the whole universe of potential entrepreneurs, rather than just of the existing business owners, and hence analyse the choice of entrepreneurial activity. This is particularly beneficial when analysing the different choices of male and female entrepreneurs. As suggested by Berglann et al. (2009) in a single country context, cross-gender differences are better captured by a wider definition of entrepreneurship.

Moreover, our approach to the impact of institutions differs from that developed thus far in the literature. Previous studies, including those using GEM (see e.g. Bowen and de 
Clerk, 2008) only employ country level averages of entrepreneurial indicators to identify institutional influences. However, we would argue that the impact of institutions can best be explored using cross-country variation to explain individual entrepreneurial entry decisions.

Finally, most studies of the impact of institutions face serious problems of multicollinearity between the various indicators, which are typically resolved by the use of ad hoc specifications based on an arbitrary exclusion of indicators leading to omitted variable issues. Our use of data reduction techniques yields robust principal factors easily capable of economic interpretation.

The gender approach to economic issues can be justified on three different (and often complementary) grounds: equality, merit / efficiency, and need (Jacquette, 1990; Razavi, 1997). The starting point for the first approach is the basic moral and philosophical assumption about equality of rights between men and women. The second relies on the economic argument that any form of discrimination is economically inefficient. The third points out that women poverty and related issue of children poverty is an important social problem that calls for institutional reform restoring equilibrium between male and female economic positions. From all three perspectives, entrepreneurship appears as critical: the adequate role of women in new venture creation, ownership and growth may lead to their empowerment and may induce structural change that goes hand in hand with institutional reform. It is the broader objective of this paper to contribute to that agenda.

The remainder of the paper is organised as follows. In Section 2 we provide a brief overview of the literature about female entrepreneurship and institutions and present our hypotheses. The dataset, methodology and our approach to quantifying the institutional environment is outlined in the third section and the fourth reports our results. We present our conclusions and interpretations in Section 5. 


\section{Female Entrepreneurship and Institutions}

This section begins by considering the institutional literature and discussing how institutions may influence entrepreneurship in general, and female entrepreneurship in particular. In fact, the specific literature on female entrepreneurship and institutions is quite thin, but we report on the growing body of knowledge about finance and female entrepreneurship. On this basis, we go on to present the hypotheses to be tested in the remainder of the paper.

\subsection{Institutional theory}

According to North (1990), organizations set up by entrepreneurs adapt their activities and strategies moulding them to fit the opportunities and limitations provided through the formal and informal institutional framework. Though ideally, formal rules are designed to facilitate exchange reducing transaction costs (Williamson, 1985; 2000), they are also likely to affect individuals or groups in different ways. Since private interests may differ and individuals, who often have their narrow interests at heart, affect formal rules and institutions: the latter are not necessarily shaped in the interest of social well-being (North 1994; Olson, 2000). Where social groups are easily identified, as it is in the case of gender, opportunities for discrimination arise. Correspondingly, institutions can be maintained even if they are inefficient (DiMaggio \& Powell 1983; North 1990). Formal institutions have a tenacious ability to survive because they become intertwined with habitual behaviour (i.e. culture) providing stability (Crawford and Ostrom, 1995). Institutions may change slowly due to the influence of path dependence. This occurs because institutional change is usually incremental (North 1990:10). Thirdly, lock-in can occur as a result of a symbiotic 
relationship between existing institutions and the organizations that have evolved as a result of the incentive structure provided by those institutions (ibid. 1990:7; Dixit, 2004). Even when the formal rules change, organizations which benefited from the outdated informal rules and which would lose their 'comparative advantage' if they adopted new informal practices complementary to formal rule changes will continue to participate in detrimental informal rule practices in order to retain their advantage.

North and Thomas (1973), Williamson (1985), Barzel (1997), Rodrik (2000), Acemoglu and Johnson (2005) and others have argued that the property rights system forms the backbone of the market economy. In essence, strong legal property rights (rule of law) support the broader dimension of economic property rights that are defined as "individual ability, in expected terms, to consume the good (or the services of the asset) directly or to consume it indirectly through exchange” (Barzel, 1997, p.3). Accordingly, in recent institutional research, the focus shifts from the assignment of rights and certification to the institutional environmental conditions that make execution of these rights, especially exchange and other legal contracts based on the property rights, effective. One important issue relates to the accessibility of these rights to the population as a whole, which may have critical implications for the extent and performance of the entrepreneurial sector (Sonin, 2003; De Soto, 2001). Moreover, in many countries around the world, universality of property rights is undermined by gender specific restrictions related to ownership rights, free transferability of assets and more generally contract rights of women (Jütting et al. 2006).

Property rights have further implications for financial issues. One of the immediate benefits from the access to the formal property rights system is that it can create a basis for low transaction cost financial contracts and a virtuous circle of creation of assets and finance (De Soto, 2001). 


\subsection{Institutions and Entrepreneurship}

Baumol (1990) argued that entrepreneurial activity could take productive, nonproductive and even destructive forms, depending on the institutional context. Institutions and the associated incentives and penalties for particular types of economic behaviour determine the balance between these three forms, with higher quality institutions motivating entrepreneurs to choose productive over value-reducing activities. This framework partially motivates our analysis. We commence with potential entrepreneurs who can be viewed as maximizing their expected return when making a decision to start new ventures (Casson, 1982). In contexts where institutions are functioning effectively, risks are primarily limited to factors associated with the nature of the ventures themselves and the characteristics of the individuals’ involved (Schumpeter, 1934; Kirzner, 1973). Moreover, in a developing economy context, weak institutions may increase net returns to non-productive or even criminal activity, reducing incentives to enter (productive) entrepreneurship. Three specific aspects of the inter-relationship between entrepreneurial activity and institutions have been found to be among the most important in the literature (Johnson et al., 2002; Dermirguc-Kunt et al., 2006; Klapper et al., 2006). The first is the system of property rights. Weaknesses in property rights increase transaction costs, possibilities to use resources indirectly via contracts and the riskiness of entrepreneurial activity. Recent theories of entrepreneurship emphasise that "the institution of private property ... has an important psychological dimension that enhances our feelings of ... internal control and personal agency, and it thereby promotes entrepreneurial alertness” (Harper 2003, p. 74). The second concerns the welfare and tax system, which influence both the opportunity cost and the net financial return to entrepreneurial activity. Finally, the quality of financial institutions influences 
entrepreneurs' ability to access capital and therefore, for example, to start their businesses at a cost-minimising scale or to survive short term negative shocks.

De Soto (2001) argues that the lack of well-defined and efficient system of registering, protecting and trading of property rights may be the key obstacle that prevents the entrepreneurs from utilising and combining the potentially productive assets and turning them into real capital (see also Rodrik, 2000). Acemoglu and Johnson (2005) emphasise the critical role for the functioning of a market economy of constraints on the executive branch of the government, and this defines both elements of protection and stability of property rights. In their approach, property rights are akin to the related, but slightly wider concept of the rule of law, as the latter corresponds to a stable institutional framework restraining the erratic use of power by politicians and public administrators.

The relationship between property rights and entrepreneurship has been considered in previous empirical work, but the results have been ambiguous. The property rights indicator was not found to be significant by Klapper et al. (2006), Desai et al. (2003) or DemirgucKunt et al. (2006), possibly because of their focus on incorporated companies. However, Johnson et al. (2002) suggest that the insecurity of property rights may be a key factor deterring investment in small manufacturing firms. The impact of quality of property rights on female entrepreneurship relative to male has not yet been considered empirically. We also consider the impact of the extent of state sector on entrepreneurship. In general, a larger state sector will militate against entrepreneurial activity, both via state revenues and expenditures. Taxes and welfare provision may affect entrepreneurial entry via their direct impact on expected returns to entrepreneurial activity and its opportunity cost. High and increasing marginal level of taxes may weaken incentives for opportunity-driven entrepreneurship by reducing potential gains, while high levels of welfare support provide alternative sources of 
income and therefore by increasing the alternative wage may reduce the net expected return to entrepreneurship. Taken together, this indicates that a larger state sector will crowd out entrepreneurial activity.

An efficient system of property rights may be a necessary but is not a sufficient condition for a well-developed financial system. While rule of law creates potential for entrepreneurship, an efficient financial system implies that this potential may be realised by enabling access to resources by those who have entrepreneurial human capital, but lack wealth. Here, efficiency stems from the fact that distribution of wealth and distribution of entrepreneurial talent are not correlated. In practice, property rights and developed financinal systems do not necessarily go together: one can find countries which have implemented a relatively efficient system of property rights, while their financial system remains underdeveloped, for example some of the countries that switched from a command to market economy. In these cases, entrepreneurs may be unable to carry through their projects, either because the cost of finance is too high or because they face binding financial constraints (Gros and Steinherr, 2004; Mickiewicz, 2005).

The distinction between formal and informal institutions is particularly relevant when one considers financial institutions. While developed formal financial sector relies on the rule of law, informal finance does less so. Entrepreneurs may rely on informal sources of finance, even when financial institutions are well developed, because they do not have collateral or wish to avoid risk from assuming debt or because of discrimination. There is debate about whether this phenomenon affects male and female entrepreneurship differentially (e.g. Carter and Rosa, 1998).

\subsection{Institutions and Female Entrepreneurship}


The GEM studies have shown that there is considerable variation in the proportion of people undertaking entrepreneurial activity who are female across countries. Female entrepreneurs are everywhere in the minority but the variation is large. Minniti et al. (2005a) report variation of female total entrepreneurial activity rate between 1.2\% in Japan and 39\% in Peru. Some cross country analysis of entrepreneurship is beginning to appear. Thus, there is work attempting to explain female entrepreneurship rates across countries with reference to education and experience (Brush,1990) and analysing cross country variation in entrepreneurial activity in terms of institutions (e.g. Klapper et al., 2006). However, with a notable exception of Verheul, van Stel and Thurik (2006), who aim to explain differences in female and male entrepreurship based on a sample of 29 country-level data points, the literature has not yet addressed the question of whether institutions affect male and female entrepreneurs differently.

Yet there are a number of reasons to believe that this should be done. The findings to date establish some significant gender differences in certain determinants of entrepreneurial activity which seem likely to be associated with the quality of institutions. These form the basis for our subsequent theoretical development and hypotheses. Thus, the literature has established that education and birth order have the same impact on female as male entrepreneurs (Schwartz, 1976; Hisrich and Brush, 1984; Greene et al., 2003), while age profiles for both genders may differ (Berglann et al., 2009). In addition, some authors have identified significant differences with respect to access to resources. Thus though Verheul and Thurik (2001) and Coleman (2000) found no differences between the proportions of debt and equity used by male as against female entrepreneurs, Carter and Rosa (1998) identified gender differences in financing entrepreneurial activity; while men used more capital at start up, women were less likely to use formal financial instruments like bank loans or supplier 
credit. Bruce (1999) indicated there might be an important role for informal finance in female entrepreneurial activity by establishing that the presence of an employed husband led to interfamily capital transfers, helping women to become self-employed (see also Verheul et al, 2006; Greene et al, 2003).

Since the institutional context is typically taken for granted in country level studies, there has been little consideration of the role of institutions on female entrepreneurship. However, one might argue that men tend to have stronger advantages in business entry in countries where property rights are weak and institutional barriers to entrepreneurship are high. In such a situation, entrepreneurship depends especially on high levels of motivation, and, according to Shragg et al. (1992), negative self-perceptions in this context, are an important difference between male and female entrepreneurs. Moreover, weak property rights mean that entrepreneurs have to rely relatively more on informal networks and those networks tend to be male dominated (as exemplified by Russia (Aidis et al., 2008)); due to gender-defined social positioning, men may also be more effective dealing with government officials (Sabarwal et al., 2009). Brush (2006) concludes that male and female business networks are significantly different and that female entrepreneurs engage in less "weak-tie” networking than salaried males. In addition, the rule of law may have differential positive impact on women entrepreneurship as it is closely correlated with eliminating (or at least alleviating) institutional traits that restrict the rights of women, including their economic rights. Those restrictions may include constraints imposed on women mobility (including leaving home), marriage decisions, inadequate protection of their physical integrity (that make it difficult for them to operate independently in a wider anonymous community), restrictions of their civil liberties and direct restrictions on their property rights (Jütting et al., 2006). We therefore predict that: 
Hypothesis 1: Women are less likely than men to undertake entrepreneurial activity in countries where the rule of law is weaker.

We have argued that a large size of the state sector can limit the incentives for entrepreneurial entry both via tax effects and welfare effects, raising the opportunity cost of entrepreneurship (Verheul et al., 2001; 2006). In addition, larger scale of employment in the state sector may have a similar, more direct effect, creating alternative options for potential female entrepreneurs.

It seems likely also to have a greater negative effect on women than men as entrepreneurs. This is because, consistent with the role investment theory (England, 1984; Bielby and Bielby, 1988; Lobel, 1991, Orser et al., 2006), women’s occupational decisions are often made within the social context of a household and it is in many countries a traditional pattern is that women's' activity rates are lower than men's due to the additional burdens and responsibilities associated with domestic and caring labour. As a result, women's decisions to enter either into employment or into entrepreneurship will be more sensitive to environmental factors because the perceived opportunity cost is higher: men may enter self-employment or employment first to satisfy income needs of a given household; a pecking order of entrepreneurial entry and entry into employment may become established. In this context, a large state sector both de-motivates women by offering security and by eliminating awards. The mechanisms may partly arise because if the state sector is small, the resulting weakness of social security may create incentives for women to become economically active ${ }^{3}$. Moreover, when the state provides more services that affect

\footnotetext{
${ }^{3}$ Childcare is an interesting special case to consider. Given the social context sketched above, lack of childcare provision could induce women to stay at home. Short-term effects like this appeared in 1990s in the ex-Soviet
} 
household/families, the rewards from both employment and entrepreneurship are lower (say in terms of access to housing, education for children or healthcare). These factors may affect women more than men because of the tendency within the household to develop a genderspecific pecking order of entry into entrepreneurship and employment. In addition, as mentioned above, a larger state sector implies that markets are replaced by hierarchies and, due to socially defined gender positioning, men be in more advantageous positions while dealing with them (Saberwal et al., 2009). In contrast, markets provided they remain competitive will alleviate discrimination (Becker, 1971). ${ }^{4}$ Therefore women’s economic decisions may be more sensitive to the size of the state sector than men's and we hypothesise that:

Hypothesis 2: Women are less likely than men to undertake entrepreneurial activity in countries where the state sector is larger.

We have noted that the literature argues that female entrepreneurs may face more difficulties than men in their access to formal and informal finance. In a recent overview, Marlow and Patton (2005) explain why women encounter barriers in their access to formal (predominantly banking) finance and to informal business angels' funding. Barriers in access to bank finance can be viewed as related to discrimination and to women's position on the labour market, notably the gender pecking order of employment. As lower paid and discontinuous jobs are more likely for women, they are not in a position to accumulate such

block. However, in equilibrium, state-sponsored childcare will also affect decisions to have children, so the net long-term effect on female activity rates is not obvious a priori.

${ }^{4}$ This discussion concerns the size of the state sector but government-sponsored legislation that may combat discrimination. The latter is associated with the rule of law, which implies universality and lack of discrimination, as previously discussed. However, there may be complementarity between the two: a larger state sector replaces competition with hierarchies and makes special legislation combating discrimination more urgent. 
level of collateral as men, affecting the size and availability of bank loans. For similar reasons, their credit track record tends to be less consistent. In addition, due to their typical domestic and caring duties, women tend to chose sectors that offer more flexible employment opportunities, but are more crowded and therefore most risky (individual consumer oriented services in particular which may also cause difficulties in obtaining bank finance). Similar reasoning applies to informal funding. Marlow and Patton (2005) point out that provision of informal capital tend to be dominated by men, and it may lead to negative network effects placing women in disadvantage. We therefore posit that an increased supply of formal and informal finance will have a beneficial effect on entrepreneurial finance for women: as they tend to have more 'marginal' position in terms of access to both, increased supply should affect them more strongly than men. Again, the broader intuition behind this effect is that increased supply of finance leads to more competition and less discrimination against women (Becker, 1971; Muravyev et al., 2009).

This leads to our final two hypotheses:

Hypothesis 3: Women are less likely than men to undertake entrepreneurial activity in countries where the formal financial sector is weaker.

Hypothesis 4: Women are less likely than men to undertake entrepreneurial activity in countries where the informal financial sector is weaker. 


\section{Data and Methods}

In this section we consider the data used in our empirical work, including the development of factors to describe the institutional environment (see also: Aidis et al., 2009). We go on to describe our estimation techniques.

\subsection{Indicators Corresponding to Economic Institutions}

Economic institutions are difficult to measure and multicollinearity is a serious problem leading to ad hoc specifications. Here we rely on data reduction methods using Heritage Foundation / Wall Street Journal indicators. In principle, one might want to consider the World Bank 'Doing Business' database as an important alternative to the Heritage indicators. However, 'Doing Business' does not match the time frame of the GEM surveys that are available. We could extrapolate backwards, yet we were concerned that there is a strong component of time variation in 'Doing Business' indicators. Finally, the factor analysis collapses when applied to 'Doing Business' database, mainly due to the pattern of missing values. 
The Heritage Foundation offers fifty independent indicators grouped into ten broad institutional categories related to: trade policy, fiscal burden (including marginal tax rates), size of the government sector (government expense) in the economy, monetary policy (control of inflation), constraints on foreign investment, direct state involvement in banking and finance and regulatory restrictions that go beyond prudential supervision, regulation of labour (employment and wages), security of property rights, business regulations (which include entry barriers), corruption. These ten categories are intended to outline the institutional factors that taken together determine the degree to which economic actors are free to respond to changing world market conditions (Beach and Kane (2007)).

We have noted that multicollinearity is a serious issue in institutional analysis, because of the abundance of closely related indicators and that applies to the Heritage dataset. Theory can guide us on the relative importance of different institutional dimensions but is of limited assistance when considering the choice of alternative measures of related institutional features. We apply factor analysis to tackle the problem, utilizing the entire Heritage dataset (1995-2008 including 164 countries and nine indicators) available on the Heritage Foundation's website. ${ }^{5}$ Based on the screeplot, there is a distinct break after the second factor, as the eigenvalue drops from 1.30 to 0.27 . Accordingly, following the standard practice (see Russell, 2002; Pett et al., 2003; Costello and Osborne, 2005) we retain the first two factors. ${ }^{6}$ Given we have no reasons to expect that the correlation between the factors is

\footnotetext{
${ }^{5}$ As accessed in February 2008. Labour freedom is available from 2005 only and was not included. However, we verified it did not affect the results significantly. When we run factor analysis for a shorter period but with freedom of labour included, again, the first two factors explains most of the variance, and loadings of labour freedom are not high on each of them. Empirically, labour freedom is closely negatively correlated with the size of the government spending and therefore its impact is difficult to separate where the size of the government is taken into account.

${ }^{6}$ However, retaining two factors come at cost of high uniqueness value for the trade freedom indicator (at 0.71), i.e. this variable is not well explained by the extracted factors. Generally however, sampling adequacy is high: overall Kaiser-Meyer-Olkin measure is 0.85 .
} 
zero, we apply oblique rotation (via oblimin method), producing the following factor loadings illustrated by Figure 1 below. $^{7}$

\{Figure 1 about here\}

Figure 1 reveals the pivotal role of the property rights dimension among the Heritage Foundation indicators. The property rights indicator has the highest loadings on the first factor, which itself explains most of the institutional variance. It links closely with freedom from corruption (the second highest loadings on the first factor), as well as with business freedom (the third highest loading), which is related to freedom of entry and exit. Most of other institutional indicators are clustered around these. We therefore label the first factor as "rule of law".

However, Figure 1 shows that "fiscal freedom" and the size of the government spending in GDP dimensions should be best considered separately from the other institutional factors. They cluster together forming the second factor that we label "limited state sector". While the impact of taxes and the impact of government spending (including welfare) on entrepreneurship can be separated conceptually, they are obviously connected empirically via the size of the state budget, and in practice their independent effects prove difficult to identify. The factor scores for countries in our sample are reported in Figure 2 below.

\{Figure 2 about here\}

\footnotetext{
${ }^{7}$ As argued by Costello and Osborne (2005), orthogonal rotation is not utilising all available information. Moreover, if factors are truly uncorrelated, the results of oblique rotation are very similar to the results of orthogonal rotation. In our case the correlation between the two factors after oblique rotation is -0.14 . We use oblimin method following recommendation by Fabrigar et al. (1999) and Russell (2002). We also applied promax. We verified that the results based on the two are almost indistinguishable for our data.
} 
We find that the Scandinavian countries, Belgium, Netherlands and Germany are located in the upper left corner with a strong rule of law and an extensive state sector. In contrast, Hong Kong and Singapore are the two economies which combine the rule of law with a small state sector. The Anglo-Saxon economies are between these cases, with high quality institutions and a middle size range of state sector. In contrast, Latin American countries (with the notable exception of Chile), Russia, China and India are all countries where the size of government spending and taxation remains relatively low, but rule of law is weak. The weak negative correlation between the two factors is driven by the fact that there are no countries in the lower left corner of the graph. Thus, paradoxically, a large state sector cannot be built where basic institutional quality is low, because the latter affects the state's capacity to collect taxes.

Another way of interpreting the weak negative correlation between the two factors is to note that factor 1 , which we have denoted 'rule of law”, actually represents both property rights and corruption. Once we focus on corruption, our results can be contrasted with the theoretical model of Acemoglu and Verdier (2000), who argue that while state intervention may have a positive overall impact, some corruption may be unavoidable price paid for it. On our graph, this would imply a positive correlation: a larger state sector would be associated with greater corruption leading to an ordering of observations along the diagonal. However, this is not what we observe. Rather, the findings in Figure 3 are more consistent with Hellman et al. (2003): in the countries with a large state sector, corruption may be lower, perhaps because special interests become directly embedded within the state sector (see also: Mickiewicz (2009)).

Acemoglu and Verdier's perspective is motivated by the efficiency theory of institutions, which assumes that institutional outcomes have some traits of efficient feasible 
solutions. In contrast, Botero et al. (2004) argue that the institutional outcome may also be explained by political theories (assuming some entrenched special interests) and by institutional inertia (as represented by legal origin). We noted above that inefficient economic institutions may persist and both political factors and institutional continuity can contribute to the explanation.

Our hypotheses also require us to find proxies for institutions of financial intermediation. We consider both formal and informal financial development, using the size of the formal banking sector and supply of informal finance, respectively (see Korosteleva and Mickiewicz, 2008). The former is proxied by the ratio of credit to private sector to GDP, the latter by the prevalence rate of business angels (over previous three years), constructed from the Global Enterpreneurship Monitor (GEM) data as country-year level averages. Here, following GEM, 'business angels' are defined as any individuals that provide start-up finance to others.

While it would be problematic to estimate entrepreneurial entry rates without financial indicators, unavoidably we pay the price with some attenuation effects. As we noted above, while strong property rights do not automatically imply sophisticated financial markets, correlation is likely. In particular, the rule of law will probably have a positive impact on formal finance: financial contracts are complex and require special institutional support. Parallel to this, when in our regressions we include both the rule of law and financial indicators, the impact of the former is limited to its direct role. Moreover, there is a potential link between formal and informal finance: we may overestimate the impact of the latter, as we cannot easily account for the fact that it is the opportunity to accumulate financial resources in the formal financial sector that enhances subsequent supply of informal (family and friends) finance. 


\subsection{Individual Level Data}

Our individual level data are drawn from GEM and are generated through surveys creating stratified samples of at least 2,000 individuals per country. The sample is drawn from the whole working age population in each participating country and therefore captures both entrepreneurs and non-entrepreneurs. While data on business ownership and individual business financing is included, entrepreneurial activity is primarily viewed as new, nascent start-up activity. Nascent entrepreneurs are defined as those individuals between the ages of 18 - 64 years who have taken some real action toward creating a new business in the past year, and expect to own a share of those businesses they are starting, which must not have paid any wages or salaries for more than three months (Minniti et al., 2005b). In contrast, established entrepreneurs are defined as individuals who own or manage a company and have paid wages or salaries for more than 42 months (ibid.). We utilise all available GEM data from the 1998-2004 surveys including the 44 individual countries, as reported in Figure 2.

\subsection{Gender and institutions: interactive effects}

Most research indicates that men have a higher probability of becoming entrepreneurs than women (Minniti et al. 2005a; Verheul et al. 2006); in an analysis based on GEM data, men were found to be about twice as likely to be involved in entrepreneurial activities than women (Reynolds et al. 2002).

This we take as granted and to test our hypotheses we focus on interactive effects between female dummy and our four institutional dimensions corresponding to hypotheses 14 as described above. Accordingly, we consider the interaction between the female dummy 
variable and the country-level variables; rule of law, limited state sector, and availability of formal finance and informal finance.

\subsection{Control variables}

In addition to the institutional variables discussed above, we follow the literature in controlling for a number of indicators of economic development as well as various personal characteristics of entrepreneurs that might affect entrepreneurial entry. Commencing with cross-country characteristics, several studies have documented the existence of a relationship between entrepreneurial activity and economic development (Wennekers et al. 2005; Carree et al. 2002; Acs et al. 1994). We control by including a measure of per capita GDP at purchasing power parity (PPP).

The literature has also been concerned with the link between the overall (cyclical) economic performance in a country and the incentives to entrepreneurial entry. Two conflicting effects may occur, and it is difficult to decide a priori which has the stronger impact. On the one hand, entrepreneurship may be 'recession-push', as the opportunity cost of entrepreneurial entry is lower when existing firms are not expanding, which reduces new job openings. On the other hand, there may be also 'prosperity-pull' effect; that is, a growing economy leads to larger expected gains from entrepreneurial activity (Parker, 2004). The rate of economic growth measured by GDP growth has been shown by Van Stel et al. (2007) to have a positive effect on the rate of opportunity entrepreneurship. In our models we include GDP growth as a control variable.

The relationship between entrepreneurship and the supply of financial resources has an individual as well as an institutional dimension. Evans and Jovanovic (1989) show that, due to capital constraints, there is a positive relationship between the probability of becoming 
self-employed and the assets of the entrepreneur. Similarly, Evans and Leighton (1989) show that the exploitation of entrepreneurial opportunities is more common when people have greater financial capital (see also: Hurst and Lusardi (2004)). This may also be important for female entrepreneurs (Greene et al, 2003). We capture some aspects of the individual-specific financial constraints by using a dummy variable, which indicates if a potential entrepreneur had been providing funds for business financing in the past.

The most common controls for personal characteristics in the literature are for age and human capital. The relationship between entrepreneurship and age is typically found to be inverse- $\mathrm{U}$-shaped, with the maximum found at a relatively young age (Levesque and Minniti, 2006) and we use a quadratic control in our equations. Robinson and Sexton (1994) and Cooper and Dunkelberg (1987) find that the decision to become self-employed is influenced by education while the results of Delmar and Davidsson (2000) and Davidsson and Honig (2003) show an education effect for nascent entrepreneurs. More recent evidence compiled by Parker (2004) suggests that on average, entrepreneurs tend to be more educated than non-entrepreneurs and Brush (2006) confirms that these findings hold for female as well as male entrepreneurs.

Wennekers et al. (2005) found a significant and positive relationship between the number of incumbent business owners and entrepreneurial start-ups. Role models may for example help by providing information, which alleviates both uncertainty and the cost of starting the business (Minniti, 2005). We therefore also control for whether the potential nascent entrepreneur knows any other entrepreneurs.

Last but not least, start-up rates may be influenced by whether the potential entrepreneur is employed while deciding to start his/her business. Because in our theoretical interpretation, we focused on the role of women within the households and on what we called 
a 'pecking order of economic activity', we control for whether women are within or outside employment using additional interactive effects. We know from the literature that the incentives for 'offensive’ entry (from employment) and for ‘defensive’ entry (from outside employment) may be different for men and women (Berglann et al., 2009). ${ }^{8}$

Definitions and descriptive statistics for all variables are presented in Table 1.

\{Table 1 about here

\subsection{Framework for analysis}

We start with a simple description of the data based on correlations at a country level. These concern the relationship between the country-level ratios of male to female start-up rates and the institutional coefficients corresponding to the four dimensions captured by our hypotheses $1-4$.

We next move to multivariate estimations that utilise all sample information. Our core model is constructed as follows. If $\boldsymbol{i}$ denotes individuals, $\boldsymbol{j}$ denotes countries and $\boldsymbol{t}$ denotes time, we estimate an equation of the form:

Entry $_{\mathrm{ijt}}=\mathrm{f}$ (Strength of Property Rights $\mathrm{j}_{\mathrm{j}}$, Level of Welfare Provision and Taxation ${ }_{\mathrm{j}}$, Availability of Formal Finance $_{j t}$, Availability of Informal Finance ${ }_{j t}$, GDP/capita f $_{\mathrm{t}}$, GDP growth rate $\mathrm{j}_{\mathrm{j}}$, Individual Level Controls $\mathrm{s}_{\mathrm{jit}}$, Female $\mathrm{ij}_{\mathrm{jt}}$, Interactive effects between institutions and Female $\mathrm{jit}_{\mathrm{ji}}$ ), where Entry is a dummy variable denoting whether or not an individual in a particular country at a particular date is engaged in nascent start up activity. We use Probit as our

\footnotetext{
${ }^{8}$ But we verified that no other effects are sensitive to the omission of those effects; alternative specifications are available on request.
} 
estimator, reporting robust standard errors. We allow for the possibility that the observations are not independent for each country-year sample in our dataset and this is reflected in the estimated variance-covariance matrix and reported coefficients.

In addition, we explore the robustness of our results and develop our interpretation of the findings by focusing in greater depth on three issues for female entrepreneurship: high aspiration entrepreneurship; opportunity as against necessity entrepreneurship; and the structure of individual financing. The first two are based on estimates of bivariate probit models where individual equations utilise the same set of independent variables. The first focuses on the role of female entrepreneurs in high aspiration start-up; that is a start up for which respondent expects to create 10 or more jobs in five years time. To explore this, we estimate the likelihood of the 'high aspiration' entry. In the second bivariate probit model, we estimate the likelihood of opportunity driven start-up. The objective of these experiments is to establish whether our results on the gender differential in the institutional impact are driven by low aspiration or necessity entrepreneurship.

Next, to obtain more insight into the financial dimension, we estimate a model based on a subsample of GEM, actual start-ups, for which more detailed individual financing data is available. We estimate a bivariate probit model, where the two corresponding dependent variables relate to the use of informal finance and to the use of formal finance.

\section{Discussion of Results}

\subsection{Country level correlations}

Figure 2-5 present country level correlations between the ratios of female to male start-up rates and institutional indicators used to test hypotheses 1-4. We present ordinary least square lines with 5\% confidence intervals, where we found those significant. 
There is no clear cut pattern linking rule of law to the gender composition of entrepreneurship (Figure 2). On the other hand, a more limited state sector seems to correlate with a higher share of women in entrepreneurship (Figure 3). Developing countries tend to have more a limited state sector and more female entrepreneurship (with Peru and Thailand representing the two most characteristic cases); however, the correlation is also driven by heterogeneity within the high middle income and high income economies: common law legal origin countries (La Porta et al., 2008) tend to have more a limited state sector and more female entrepreneurship. In contrast, the opposite applies to French, German and Scandinavian legal origin (with notable exception of Denmark, which combines Scandinavian legal origin, large state sector and a high share of female entrepreneurship). Turning to results on finance (Figures 4 and 5), we observe that a weak positive correlation between supply of formal credit and female share in start-up is spoiled by a cluster of Latin American countries with a high female entry ratios and a small size of the formal financial sector. Informal finance has a clearer pattern, with a positive correlation driven by a handful of countries with widespread informal finance and relatively high female start-ups ratios (Uganda, Peru, and Ecuador). Some of the ex-Communist economies (Russia and Croatia in particular) are at the opposite extreme: both female entrepreneurship ratios and informal finance are weak. The latter may be explained by a general weakness of relational and social capital in the economies in which independent social structures were destroyed and the societies atomised by dictatorial regimes, and rebuilding these is proving to be a slow process.

\{Figures 2-5 about here\} 


\subsection{Multivariate estimations: probit and bivariate probit models results}

Our benchmark model results are presented in Table 2 column 1. Using probit model we regress start-up decision on a set of individual and country level variables, which include interactions with female dummy corresponding to our hypotheses 1-4. The regressions have very good fits and the controls confirm many of the findings in the literature. Thus we confirm that the probability of becoming an entrepreneur is less for women, and older people and enhanced by education, by social interaction with entrepreneurs, by being a business angel in the past and by employment status (being in employment makes entrepreneurial entry more likely). We may also note that the differences in female and male propensity to enter entrepreneurship are significantly smaller for those in employment (as documented by the interactive effect between female dummy and employment dummy); albeit the result is quantitatively small.

Turning to the cross country effects, entrepreneurship is found to be countercyclical (inversely related to GDP growth) but there is no impact from level of development (GDP per capita) in these equations which also take into account the quality of institutions.

Our first hypothesis is not confirmed. Both rule of law and its incremental effect on female entry is not significant. However, this may be because the impact of rule ceases to affect entrepreneurial behaviour above a certain threshold (see Aidis et al., 2009). To test this, we also ran models, where $5 \%$ of $10 \%$ of observations corresponding to highest income per capita were eliminated. Elimination of the few richest countries restores the significance of rule of law for entrepreneurial entry; however this does not hold for the incremental effect on female entrepreneurship, which remains insignificant.

In contrast, the effects of the limited state sector variable and its interaction with the female dummy are both highly significant at 0.001 level. To understand better the nature of 
this results and to verify its robustness we additionally check if the results hold when the same model is applied to high aspiration entrepreneurship (as defined as plans to create 10 jobs or more) and to related category of opportunity entrepreneurship (as defined by opportunity motive at start-up). The results of the corresponding estimations are presented in columns 2 and 3 of Table 2. These confirm our findings from column 1 about hypotheses 1 and 2. The rule of law variable and its interaction are never statistically significant. However, the impact of limited state sector and its incremental effect on female entrepreneurship are both positive and significant. This confirms that female entrepreneurship; high aspiration female entrepreneurship; and opportunity entrepreneurship are significantly greater in countries with a more limited state sector.

Returning to the benchmark regression in column 1 of Table 2, we find no support for hypothesis 3 in our dataset. Thus, the impact of formal finance and its incremental effect on female entry is insignificant. The same result is found in columns 2 and 3, showing that variation in our measure of the supply of formal finance also does not provide a significant explanation of high aspiration entrepreneurship or of opportunity entrepreneurship. In contrast, the supply of informal finance is found in column 1 to be highly significant all startups, and to have a positive significant incremental impact on female entrepreneurship as well. However, interestingly this interactive effect is not significant for the more "value-added" types of entrepreneurship reported in columns 2 and 3. Informal finance plays little role in high expectation, dynamic entry and that may explain why the corresponding interactive gender effect is also not significant. But the insignificance of gender interactive effects may also be partly caused by the smaller overall proportion of women in high expectation entry category $(0.4 \%)$ compared to men $(1.1 \%)$ and to the smaller proportion of woman in 
opportunity entrepreneurship (1.5\%) compared to man (3.0\%). The lower frequencies in the corresponding female categories make these effects more difficult to estimate.

In addition, to obtain more insights into the structure of these financing effects, we run equations using as based on appropriate sub-samples of actual start-ups. The dependent variables in the bivariate probits relate to the use of (informal) finance from individual providers and to the use of finance from institutional sources, in particular the banking sector. In both cases, reliance on own finance is the benchmark category. The results are reported in Table 3, and are relatively poor, probably because of very small sample size. However, we confirm the role of age, employment and education. The regressions suggest that, while men and women do not differ significantly in their use of informal finance, men are more likely to rely to formal finance. This is consistent with our earlier result on importance of informal finance for women. One may also note, that while rule of law was insignificant for entry, it has significant positive impact on use of formal finance: transaction costs of a formal financial contract related to the easily transferable and easily appropriable generalised purchasing power are significantly affected by the quality of the existing system of property rights protection, both in its enforcement mechanisms and in wider access to collateral (De Soto, 2001).

\section{Conclusions}

Aidis et al. (2009) confirmed the theoretical argument that the rule of law would play an important role in the institutional environment conducive to entrepreneurial activity, especially at lower levels of development. However, contrary to our expectations there does not seem to be any differential impact between male and female entrepreneurs. We had expected that a stronger rule of law would be associated with enhanced female specific rights 
that would combat gender inequality (Jütting et al. 2006). However, our results suggest that the key aspect for entrepreneurs in the rule of law concerns property rights and the reduction of transactions costs in doing business, and that these affect male and female entrepreneurs equally. Hence, the gender inequality that restricts women mobility and social interactions and may lead to lower start-up rates is a dimension that is not measured well by general institutional quality as captured in our rule of law indicator. Gender equality seems likely to enhance female entrepreneurial activity, but we have been unable to test this empirically. This hypothesis remains an important research agenda for the future. Alternatively, if gender inequality in access to rights is associated with a weaker rule of law, the former may still affect both female and male entrepreneurship: male entrepreneurship may also to some extent suffer as a result of constraints inflicted on women via joint effects on households.

In contrast, our results on the links between the size of the state sector and female entrepreneurship are clear-cut and robust. The size of the state sector has significant negative impact on both entry and female entry, and this applies to high aspiration and opportunity entrepreneurship as well. We interpret this result as consistent with prevailing social structures where women are more likely to take more caring and domestic responsibilities within households. It follows that women will be more responsive to trade-offs between domestic work and outside involvement, and so will respond more strongly to higher incentives to gain additional income (when level of state provision of services such as education and health are lower) and to disincentives associated with a larger state in terms of higher taxes. Moreover, since a smaller state enhances not just female entrepreneurship, but high aspiration female entry, and opportunity-driven female entry, the effect cannot be caused solely by better access to welfare support. If this were true, the 'push' factors would 
dominate. In contrast, we see that 'offensive' entrepreneurship by women suffers as well, and this is likely to be due to incentive effects caused by higher taxes.

We also show that an increase in supply of informal finance as captured at the country level has a differential positive impact on female entrepreneurial entry. The supply of informal finance has been recognised in development literature as playing an important role in female entrepreneurship. In particular, due to their family and social roles especially in less developed economies, women tend to be more restricted in their economic activities and mobility. One important function of informal finance is that it addresses these restrictions. Its role relates both to supply of credit and equity (as captured directly by our indicator), but also to opportunities of accumulation of savings that create the basis for people's own investment (Schreiner, 2001; Vonderlock and Schreiner, 2001). Here, the policy lesson reinforces the point made by De Soto (2001) on the importance of informal institutions; they substitute for inadequate formal institutions, which are slow to build. Moreover, in the process of institutional reform, care should be taken to ensure consistency with local informal structures; destroying the latter as a cost of building new formal institutions may do more harm than good. The most efficient process of institution building takes a gradual form, where informal institutions are formalised and supported instead of being destroyed. This applies to informal micro finance structures in particular. We expand this discussion by establishing robust cross-country based evidence that informal financial structures are particularly beneficial for women entrepreneurship. 


\section{References}

Acemoglu, Daron and Simon Johnson. 2005. “Unbundling Institutions” Journal of Political Economy 113 (5): 949-995.

Acemoglu, Daron and Thierry Verdier. 2000. “The Choice between Market Failures and Corruption” American Economic Review 90 (1): 194-211.

Acs, Zoltan, David Audretsch and David Evans. 1994. "Why does the self-employment rate vary across countries and over time?” Discussion Paper 871. London: CEPR.

Aidis, Ruta, Saul Estrin and Tomasz Mickiewicz. 2008. "Institutions and Entrepreneurship Development in Russia: A Comparative Perspective” Journal of Business Venturing, 23 (6): 656-672.

. 2009. “Entrepreneurial Entry: Which Institutions Matter?” Discussion Paper Series 7278. London: CEPR.

Algan, Yann and Pierre Cahuc. 2007. "The Roots of Low European Employment: Family Culture?” In Christopher Pissarides and Jeffrey Frenkel, eds., NBER International Seminar on Macroeconomics 2005. Cambridge MA: MIT Press, 65-109.

Barzel, Yoram. 1997. The Economic Analysis of Property Rights. Cambridge, UK: Cambridge University Press.

Baumol, William. 1990. "Entrepreneurship: productive, unproductive, and destructive”. Journal of Political Economy 98 (5): 893-921.

Beach, William and Tim Kane. 2007. Methodology: Measuring the 10 Economic Freedoms. Washington DC: The Heritage Foundation. Retrieved March 5, 2009 from http://www.heritagefoudation.org

Becker, Gary. 1971. The Economics of Discrimination. Chicago IL: University of Chicago Press.

Berglann, Helge, Espen Moen, Knut Røed and Jens Skogstrøm. 2009. "Entrepreneurship: Origins and Returns”. Discussion Paper 4250. Bonn: IZA.

Bielby, Denise and William Bielby. 1988. "She Works Hard for the Money: Household Responsibilities and the Allocation of Work Effort” American Journal of Sociology 93 (5): 1031-1059.

Botero, Juan, Simeon Djankov, Rafael La Porta, Florencio Lopez-de-Silvanes and Andrei Shleifer. 2004. “The Regulation of Labor”. Quarterly Journal of Economics 119 (4): 13391382.

Bowen, Harry and Dirk de Clercq. 2008. "Institutional Context and Allocation of Entrepreneurial Effort”. Journal of International Business Studies 39 (4): 747-67. 
Bruce, Donald. 1999. "Do Husbands Matter? Married women entering self-employment” Small Business Economics 13 (4): 317-29.

Brush, Candida. 1990. Women and enterprise creation: Barriers and opportunities. Paris: Organization for Economic Cooperation and Development.

Brush, Candida. 2006. "Women Entrepreneurs: A Research Overview”. In: Mark Casson, Bernard Yeung, Anuradha Basu, and Nigel Wadeson, eds., Oxford Handbook of Entrepreneurship. Oxford UK: Oxford University Press.

Carree, Martin, André van Stel, Roy Thurik and Sander Wennekers. 2002. £Economic Development and Business Ownership: An analysis using data of 23 OECD countries in the period 1976 - 1996”. Small Business Economics 19 (4): 271 - 290

Carter, Sara and Peter Rosa. 1998. "The financing of male- and female-owned businesses". Entrepreneurship and Regional Development 10 (3): 225-242.

Casson, Martin. 1982. The Entrepreneur. An Economic Theory. Oxford UK: Martin Robertson.

Coleman, Susan. 2000. “Access to Capital and Terms of Credit: A Comparison of Men- and Women-Owned Small Businesses”. Journal of Small Business Management 38 (3): 37-52.

Cooper, Arnold C. and William Dunkelberg (1987). „Entrepreneurial Research: Old Questions, New Answers and Methodological Issues”. American Journal of Small Business 11 (3): 11-23.

Costello, Anna and Jason Osborne. 2005. "Best Practices in Exploratory Factor Analysis". Practical Assessment, Research \& Evaluation 10 (7): 1-9.

Crawford, Sue and Elinor Ostrom. 1995. “A Grammar of Institutions”. American Political Science Review 89 (3): 582-600.

Davidsson, Per and Benson Honig. 2003. "The Role of Social and Human Capital among Nascent Entrepreneurs”. Journal of Business Venturing 18 (3): 301-331

Delmar, Frédéric and Per Davidsson. 2000. "Where do they come from? Prevalence and characteristics of nascent entrepreneurs”. Entrepreneurship and Regional Development 12 (1): 1-23.

Demirguc-Kunt, Asli, Inessa Love and Vojislav Maksimovic. 2006. "Business Environment and the Incorporation Decision”. Journal of Banking and Finance 30 (11): 2967-2993.

Desai, Mihir, Paul Gompers and Josh Lerner. 2003. „Institutions, Capital Constraints and Entrepreneurial Firm Dynamics: Evidence from Europe”. Harvard Negotiation, Organizations and Markets Research Papers 03-59.

De Soto, Hernando. 2001. The Mystery of Capital. (London: Black Swan. 
DiMaggio, Paul and Walter Powell. 1983. "The Iron Cage Revisited: Institutional Isomorphism and Collective Rationality in Organizational Fields”. American Sociological Review 47 (1): 147-160.

Dixit, Avinash. 2004. Lawlessness and Economics. Princeton: Princeton University Press.

England, Paula. 1984. "Wage Appreciation and Depreciation: A Test of Neoclassical Economic Explenations of Occupational Sex Segregation”. Social Forces 62 (3): 726-800.

Evans, David and Boyan Jovanovic. 1989. “An Estimated Model of Entrepreneurial Choice Under Liquidity Constraints”. Journal of Political Economy 97 (4): 808 - 827.

Evans, David and Leighton L. (1989). "Some Empirical Aspects of Entrepreneurship. American Economic Review” 79 (3): 519 - 535.

Fabrigar, Leondre, Duane Wegener, Robert MacCallum and Erin Strahan. 1999. Evaluating the use of exploratory factor analysis in psychological research. Psychological Methods 4 (3), 272-299.

Giavazzi, Francesco, Fabio Schiantarelli and Michel Serafinelli. 2009. "Culture, Policies and Labour Market Outcomes”. NBER Working Paper 15417.

Greene, Patricia, Candida Brush, Myra Hart and Patrick Saparito. 2001. "Patterns of venture capital funding: is gender a factor?” Venture Capital 3 (1): 63-83.

Greene, Patricia, Myra Hart, Elizabeth Gatewood, Candida Brush and Nancy Carter. 2003. "Women Entrepreneurs: Moving Front and Center: An Overview of Research and Theory". Coleman White Paper Series.

Gros, Daniel and Alfred Steinherr. 2004. Economic Transition in Central and Eastern Europe. Cambridge UK: Cambridge University Press.

Harper, David. 2003. Foundations of Entrepreneurship and Economic Development. Abingdon: Routledge.

Hellman, Joel, Geraint Jones and Daniel Kaufmann. 2003. "Seize the State, Seize the Day: State Capture and Influence in Transition Economies", Journal of Comparative Economics, 31 (4): 751-773.

Hisrich, Robert D. and Candida G. Brush. 1984. "The Woman Entrepreneur: Management Skills and business problems”, Journal of Small Business Management, 22 (1): 30-37.

Hurst, Erik and Annamaria Lusardi. 2004. Liquidity Constraints, Household Wealth and Entrepreneurship. Journal of Political Economy 112 (2): 319-347.

Jacquette, Jane. 1990. “Gender and Justice in Economic Development”. In Irene Tinker, ed., Persistent Inequalities. Oxford UK: Oxford University Press): 54-69. 
Johnson, Simon, John McMillan and Christopher Woodruff. 2002. "Property Rights and Finance” American Economic Review 95 (5): 1335-1356.

Jütting, Johannes, Christian Morrisson, Jeff Dayton-Johnson and Denise Drechsler. 2006. “Measuring Gender Inequality”, OECD Development Centre Working Paper No. 247.

Kirzner, Israel. 1973. Competition and Entrepreneurship. Chicago IL: University of Chicago.

Klapper, Leora, Luc Laeven and Raghuram Rajan. 2006. Entry Regulation as a Barrier to Entrepreneurship. Journal of Financial Economics, 82 (3): 591-629

Korosteleva, Julia and Tomasz Mickiewicz. 2008. "Finance and Entrepreneurial Entry”. Centre for the Study of Economic and Social Change in Europe Working Paper No 96. University College London.

La Porta, Rafael, Florencio Lopez-de-Silanes and Andrei Shleifer. 2008. "The Economic Consequences of Legal Origins”. Journal of Economic Literature 46 (2): 285-332.

Levesque, Moren and Maria Minniti. 2006. “The Effect of Aging on Entrepreneurial Behavior”. Journal of Business Venturing 21 (2): 177-194.

Lobel, Sharon. 1991. “Allocation of Investment in Work and Family Roles”. Academy of Management Review 16 (2): 507-521.

Marlow, Susan and Dean Patton. 2005. “All Credit to Men? Entrepreneurship, Finance and Gender”. Entrepreneurship Theory and Practice 29 (6): 717 - 735.

Mickiewicz, Tomasz. 2005. Economic Transition in Central Europe and the Commonwealth of Independent States. Houndmills UK: Palgrave Macmillan.

Mickiewicz, Tomasz. 2009. "Hierarchy of Governance Institutions and the Pecking Order of Privatisation: Central-Eastern Europe and Central Asia Reconsidered”, Post-Communist Economies 21 (4): 399-423.

Minniti, Maria. 2005. “Entrepreneurship and Network Externalities”. Journal of Economic Behavior and Organization 57 (1): 1-27.

Minniti, Maria, Pia Arenius and Nan Langowitz. 2005a. GEM 2004 Report on Women and Entrepreneurship. Retrieved October 19, 2007 from http://www.gemconsortium.org

Minniti, Maria, William Bygrave and Erkko Autio. 2005b. Global Entrepreneurship Monitor. 2005 Executive Report. Babson College, MA, US and London Business School, UK. Retrieved September 8, 2007 from http://www.gemconsortium.org

Muravyev, Alexander, Oleksandr Talavera and Dorothea Schäfer. 2009. “Entrepreneurs' Gender and Financial Constraints: Evidence from International Data”. Journal of Comparative Economics, 37 (2): 270-286. 
North, Douglass. 1990. Institutions, Institutional Change and Economic Performance. New York NY: Cambridge University Press.

North, Douglass. 1994. 'Economic performance over time'. American Economic Review, 84 (2): $359-368$.

North, Douglass and Robert Thomas. 1973. The Rise of the Western Word: A New Economic History. Cambridge UK: Cambridge University Press.

Olson, Mancur. 2000. Power and Prosperity. New York: Basic Books.

Orser, Barbara, Allan Riding and Kathryn Manley. 2006. "Women Entrepreneurs and Financial Capital”. Entrepreneurship Theory and Practice 30 (5): 643-665.

Parker, Simon. 2004. The Economics of Self-Employment and Entrepreneurship. Cambridge UK: Cambridge University Press.

Pett, Marjorie A., Nancy R. Lackey and John J. Sullivan. 2003. Making Sense of Factor Analysis. Thousand Oaks, CA: Sage Publications.

Razavi, Shahra. 1997. “Fitting Gender into Development Institutions” World Development 25 (7): 1111-1125.

Reynolds, Paul, William Bygrave, Erkko Autio, Larry Cox and Michael Hay. 2002. Global Entrepreneurship Monitor: 2002 Executive Report. Retrieved September 8, 3007, from http://www.gemconsortium.org

Robinson, Peter and Edwin Sexton. 1994. "The Effect of Education and Experience on SelfEmployment Success”. Journal of Business Venturing 9 (2): 141-156.

Rodrik, Dani. 2000. "Institutions for High-Quality Growth: What They Are and How to Acquire Them”. Studies in Comparative International Development 35 (3): 3 - 31

Russell, Daniel. 2002. "In Search of Underlying Dimensions: The Use (and Abuse) of Factor Analysis”. Personality and Social Psychology Bulletin 28 (12): 1629-1646.

Sabarwal, Shwetlena, Katherine Terrell and Elena Bardasi. 2009. "How do Female Entrepreneurs Perform? Evidence from Three Developing Regions”. Paper presented at the World Bank conference on Female Entrepreneurship, mimeo.

Schreiner, M. (2001). “Informal Finance and the Design of Microfinance”. Development in Practice, 11 (5): 637-640.

Schumpeter, Joseph. 1934. The Theory of Economic Development. Cambridge, MA: Harvard University Press.

Schwartz, Eleanor. 1976. “Entrepreneurship: A New Female Frontier”. Journal of Comtemporary Business 5 (1): 47-76. 
Shragg, P., L. Yacuk and A. Glass. 1992. "Study of Barriers Facing Albertan Women in Business”. Journal of Small Business and Entrepreneurship 9 (4): 40-49.

Sonin, Konstantin. 2003. "Why the Rich may Favor Poor Protection of Property Rights". Journal of Comparative Economics 31 (4): 715-731

Van Stel, André, David Storey and Roy Thurik. 2007. “The Effect of Business Regulations on Nascent and Young Business Entrepreneurship”. Small Business Economics 28 (2-3): 171 $-186$.

Verheul, Ingrid and Roy Thurik. 2001. “Start-up Capital: Does Gender Matter?”. Small Business Economics 16 (4): 329-341.

Verheul, Ingrid, Sander Wennekers, David Audretsch and Roy Thurik. 2001. “An Eclectic Theory of Entrepreneurship”. Tinbergen Institute Discussion Papers No 030/3.

Verheul, Ingrid, André van Stel and Roy Thurik. 2006. "Explaining female and male entrepreneurship across 29 countries”. Entrepreneurship and Regional Development, 18 (2): 151-183.

Vonderlack, R. \& Schreiner, Mark (2002). "Women, Microfinance, and Savings: Lessons and Proposals”. Development in Practice, 12 (5): 602-612.

Wennekers, Sander, André van Stel, Roy Thurik and Paul Reynolds. 2005. "Nascent Entrepreneurship and the Level of Economic Development”. Small Business Economics 24 (3): $293-309$.

Williamson, Oliver. 1985. The Economic Institutions of Capitalism. Firms, Markets, Relational Contracting. New York: The Free Press.

Williamson, Oliver. 2000. “The New Institutional Economics: Taking Stock, Looking Ahead”. Journal of Economic Literature 38 (3): 595-613. 
Table 1. Descriptive statistics

Variable:

Entrepreneurial entry (start-up)

High expectations start-up (10 jobs or more)

Opportunity driven start-up

Male

Owner/man. of exist. Business

Business angel in past 3 years

Knows entrepreneurs in past 2 years

In employment at time of survey

Education: secondary or more

Education: postsec. or more

Education: higher

Age

Annual GDP growth rate

Log GDP pc (ppp)

Rule of law (factor 1 score)

Limited size of the government (factor 2 score)

Credit to priv. sector / GDP

$\begin{array}{lrrrl}\text { Obs } & \text { Mean } & \text { Std.Dev } & \text { Min } & \text { Max } \\ 503466 & 0.03 & 0.18 & 0.00 & 1.00 \\ 503466 & 0.01 & 0.08 & 0.00 & 1.00 \\ 503077 & 0.02 & 0.15 & 0.00 & 1.00 \\ & & & & \\ 503466 & 0.47 & 0.50 & 0.00 & 1.00 \\ 503466 & 0.05 & 0.22 & 0.00 & 1.00 \\ 501983 & 0.03 & 0.16 & 0.00 & 1.00 \\ 408828 & 0.35 & 0.48 & 0.00 & 1.00 \\ 484814 & 0.49 & 0.50 & 0.00 & 1.00 \\ 460982 & 0.67 & 0.47 & 0.00 & 1.00 \\ 460982 & 0.32 & 0.47 & 0.00 & 1.00 \\ 460982 & 0.08 & 0.26 & 0.00 & 1.00 \\ 471037 & 42.97 & 16.99 & 1.00 & 104.00 \\ 503466 & 2.95 & 2.45 & -10.89 & 10.06 \\ 503466 & 10.04 & 0.65 & 6.69 & 10.75 \\ 503466 & 1.26 & 0.75 & -0.87 & 2.28 \\ 503466 & -0.88 & 1.17 & -3.28 & 1.71 \\ 500583 & 108.80 & 44.85 & 6.88 & 231.08\end{array}$




\section{Table 2_Estimation Results}

(1) Entreprenurial entry

\section{Dependent \\ I}

Female

Owner/man. of exist. business

Business angel in past 3 years

Knows entrepreneurs

In employment

In employment * female

Education: secondary or more

Education: postsec. or more

Education: higher

Age

Age squared

Annual GDP growth rate

Log GDP pc (ppp)

Rule of law

Limited state sector

Credit to priv. sector / GDP

Informal finance prevalence

Rule of law * female

Limited state sector $*$ female

Credit / GDP * female

Informal finance * female

Constant

Number of observations

Wald Chi squared

Log pseudolikelihood

Pseudo R squared

Robust

$-0.24 * * * \quad 0.04$

$-0.07 * 0.03$

$0.37 * * * \quad 0.03$

$0.50 * * * \quad 0.02$

$0.11 * * * \quad 0.03$

$0.04+0.02$

$0.06+0.03$

$0.09 * * * \quad 0.02$

$0.10 * * \quad 0.03$

$0.01 \quad 0.01$

$-0.00 * * \quad 0.00$

$-0.02 * * \quad 0.01$

$0.01 \quad 0.07$

$-0.03 \quad 0.05$

$0.12 * * * \quad 0.02$

$-0.00 \quad 0.00$

$4.31 * * * \quad 1.27$

$0.00 \quad 0.02$

$0.05 \quad * * * \quad 0.01$

$-0.00 \quad 0.00$
0.76

$-2.15 * * * \quad 0.61$

360,697

3,350

$-52,193$

0.12
(2) High-aspiration entry

Start-up, expects $>10$ jobs

Coef. Std.Err.

$0.76+0.45$
Robust

Coef. Std. Err.

$-0.34 * * * \quad 0.05$

$-0.01 \quad 0.03$

$0.43 * * * \quad 0.03$

$0.50 \quad * * * \quad 0.02$

$0.11 * * * \quad 0.03$

$0.06+0.03$

$0.11 * * * \quad 0.03$

$0.13 * * * \quad 0.02$

$0.07 * 0.04$

$0.01 * * \quad 0.00$

$-0.00 * * * \quad 0.00$

$0.00 \quad 0.01$

$0.04 \quad 0.07$

$0.02 \quad 0.06$

$0.10 * * * \quad 0.02$

$\begin{array}{ll}-0.00 & 0.00\end{array}$

$2.25 \quad 1.39$

$-0.03 \quad 0.03$

$0.06 * * * \quad 0.02$

$0.00 \quad 0.00$

$0.59 \quad 0.52$

$-3.53 * * * \quad 0.61$

360,697

5,828

$-59,220$
(3) Entry: opportunity

Start-up: opportunity

Robust

Coef.

Std. Err.

$-0.25 * * * \quad 0.04$

$-0.04 \quad 0.03$

$0.35 * * * \quad 0.02$

$0.48 * * * \quad 0.02$

$0.15 * * * \quad 0.04$

$0.03 \quad 0.02$

$0.07 * \quad 0.03$

$0.09 * * * \quad 0.02$

$0.14 * * * \quad 0.04$

$0.01 \quad 0.01$

$-0.00 * * \quad 0.00$

$-0.02 * * \quad 0.01$

$0.03 \quad 0.07$

$0.00 \quad 0.05$

$0.11 * * * \quad 0.02$

$0.00 \quad 0.00$

4.52 *** 1.26

$0.02 \quad 0.02$

$0.05 * * * \quad 0.01$

$-0.00 \quad 0.00$

$0.77 \quad 0.61$

$\begin{array}{lll}-2.85 & * * * & 0.65\end{array}$

360,375

4,974

$-59,049$

Notes to Table 2:

1. Equation (1) estimated using probit

2. Equations (2) and (3) are estimated using bivariate probit, where in each case the second equation relates to start-up (not reported).

3. Standard errors clustered on country-years.

4. *** significant at $0.001, * *$ significant at $0.01, *$ significant at $0.05,+$ significant at 0.10 . 


\section{Table 3 Financing: Bivariate probit regression}

Dependent variable

Female

Owner/man. of exist. business

Business angel in past 3 years

Knows entrepreneurs

In employment

In employment * female

Education: secondary or more

Education: postsec. or more

Education: higher

Age

Age squared

Annual GDP growth rate

Log GDP pc (ppp)

Rule of law

Limited state sector

Credit to priv. sector / GDP

Informal finance prevalence

rate

Constant

Number of observations

Wald Chi squared

Log pseudolikelihood
Finan. from individuals

Robust

Coef.

0.05

0.04

0.07

0.09

0.15

$-0.16$

0.02

0.07

$-0.06$

$-0.04$

0.00

0.04

0.05

0.05

$-0.01$

0.00

2.40

0.23

2.29

1.33

Std. Err.

0.10

0.06

0.05

0.05

0.12

0.12

0.09

0.05

0.09

0.01

0.00

0.02

0.15

0.15

0.07

0.00

29

Institutional financing

4,454

245

$-5,854$
Robust

Coef. Std. Err.

$-0.21 * * \quad 0.07$

$-0.06 \quad 0.06$

$0.05 \quad 0.05$

$0.02 \quad 0.05$

$-0.19 * * * \quad 0.05$

$0.13 \quad 0.09$

$0.19 * * \quad 0.07$

$0.01 \quad 0.06$

$0.13 \quad 0.10$

$0.01+0.01$

$0.00 \quad 0.00$

$0.01 \quad 0.03$

$\begin{array}{ll}-0.02 & 0.14\end{array}$

$0.19+0.11$

$-0.15 * 0.06$

$0.00 * 0.00$

$\begin{array}{ll}-0.49 & 2.25\end{array}$

$-0.43 \quad 1.38$

Notes:

1. For both equations, benchmark category relates to those start-up that relate on own finance only.

2. Standard errors clustered on country-years.

3. *** significant at $0.001, * *$ significant at $0.01, *$ significant at $0.05,+$ significant at 0.10 . 
Figure 1.

\section{Factor loadings}

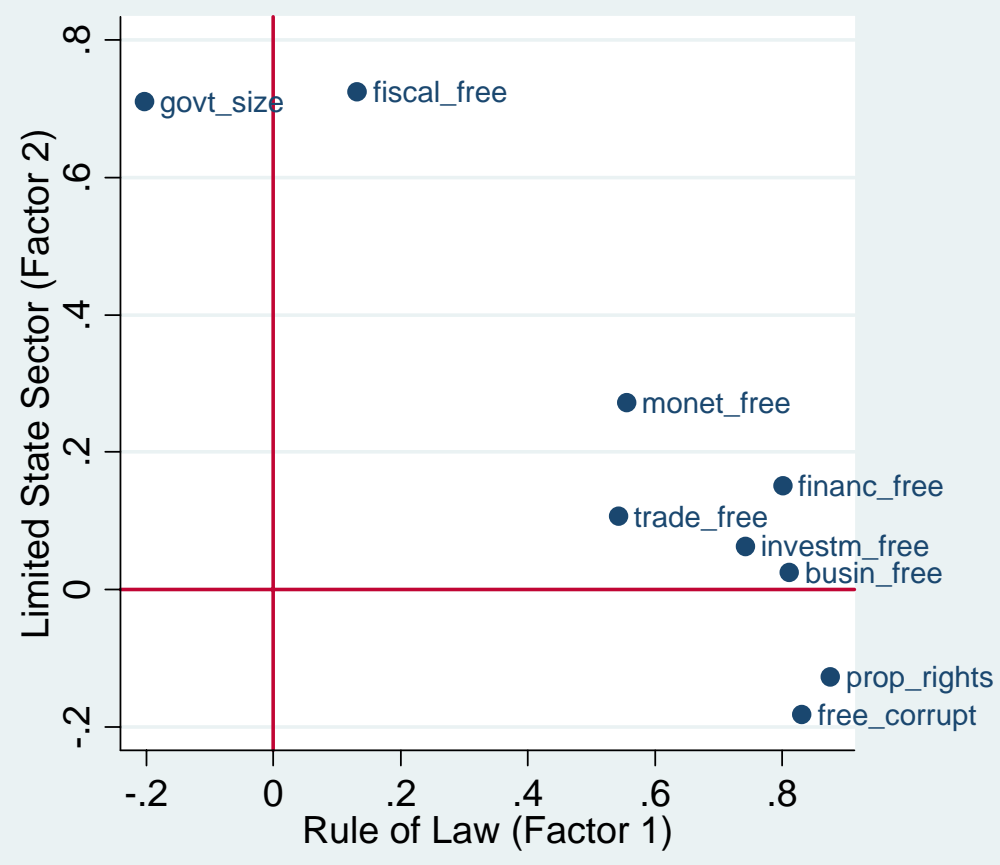

oblimin oblique rotation 
Figure 2. Factor scores for GEM countries.

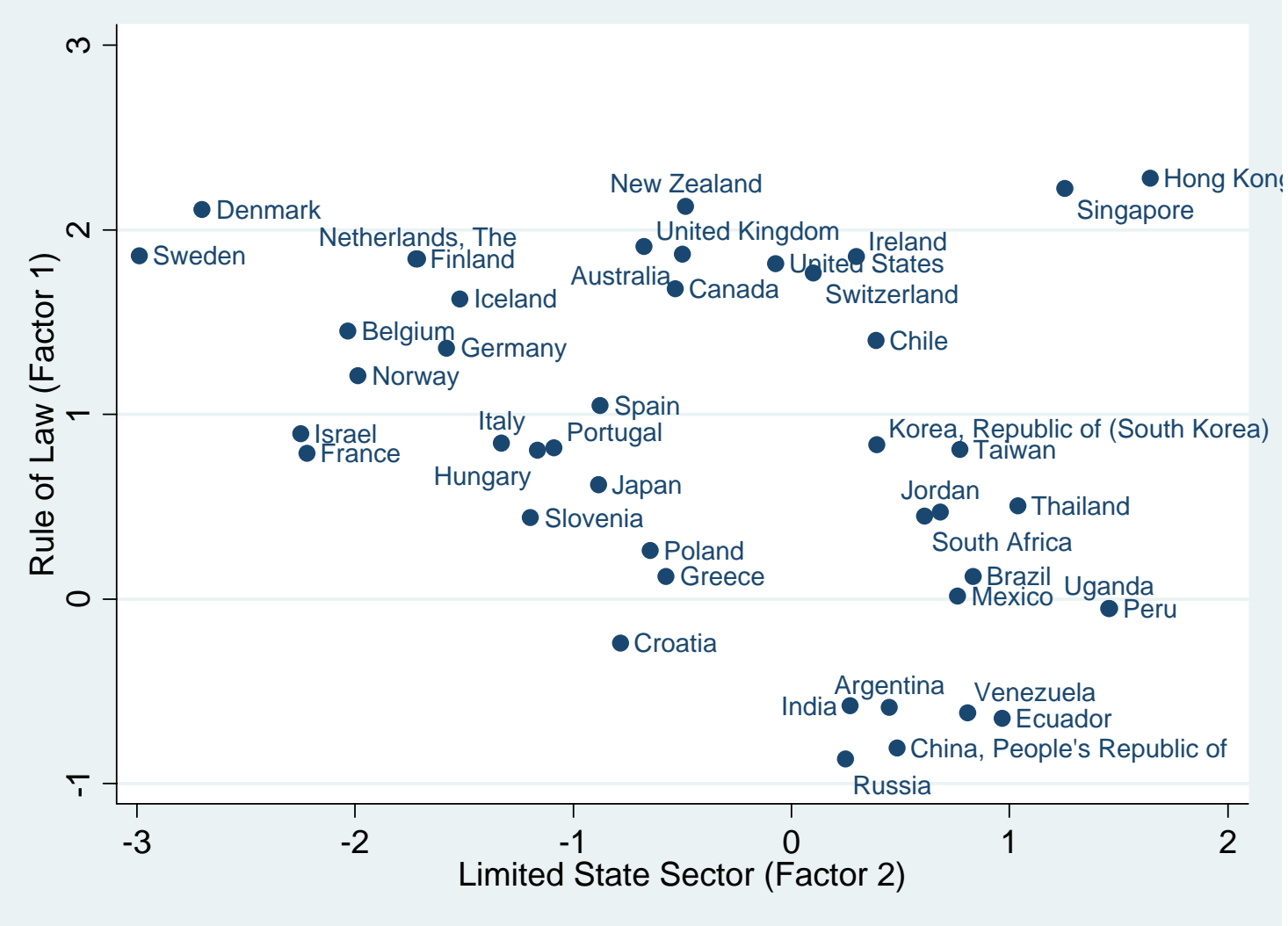


Figure 2.

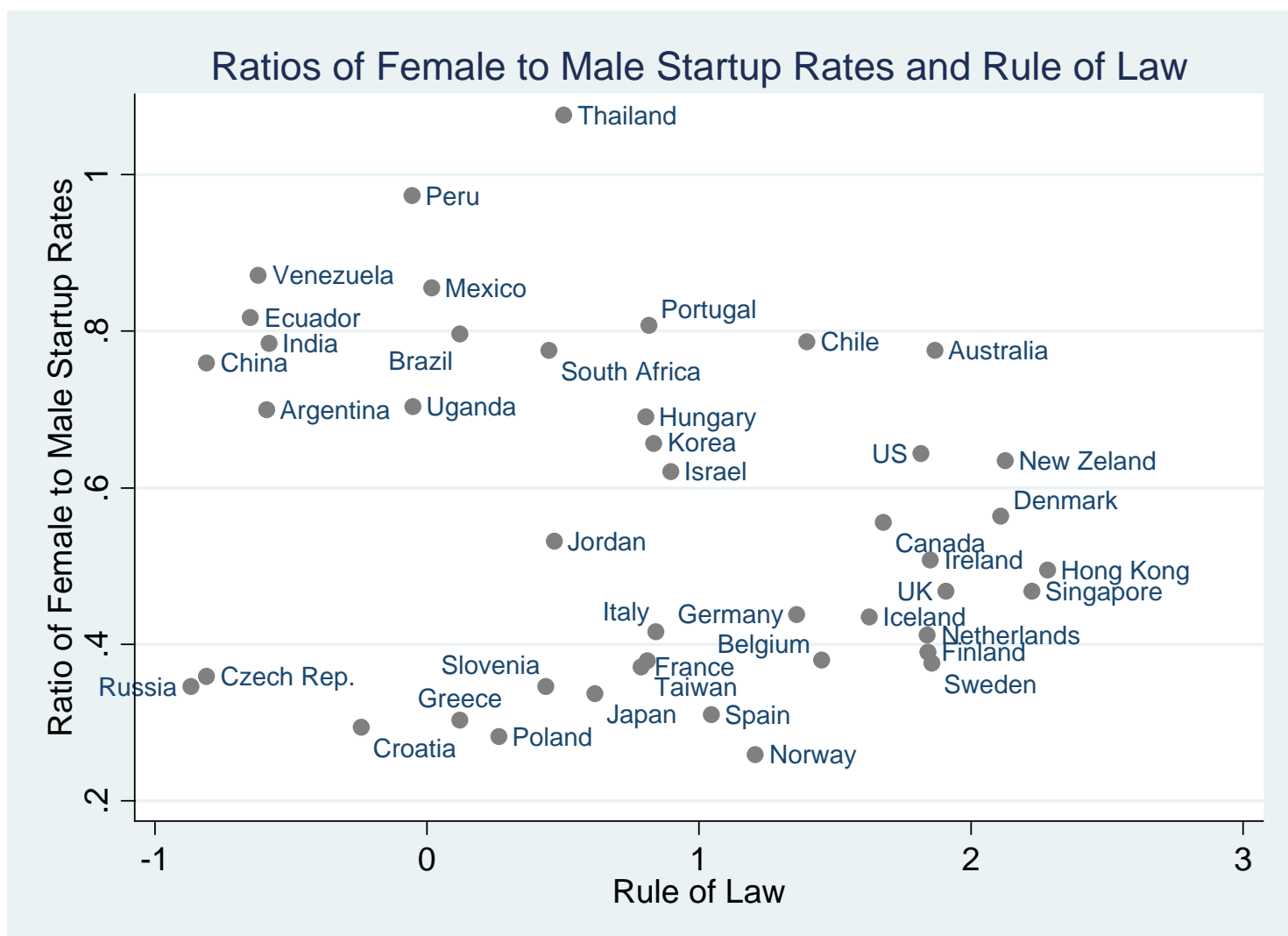

Note: the data points relate to year 2004 or latest available. 
Figure 3.

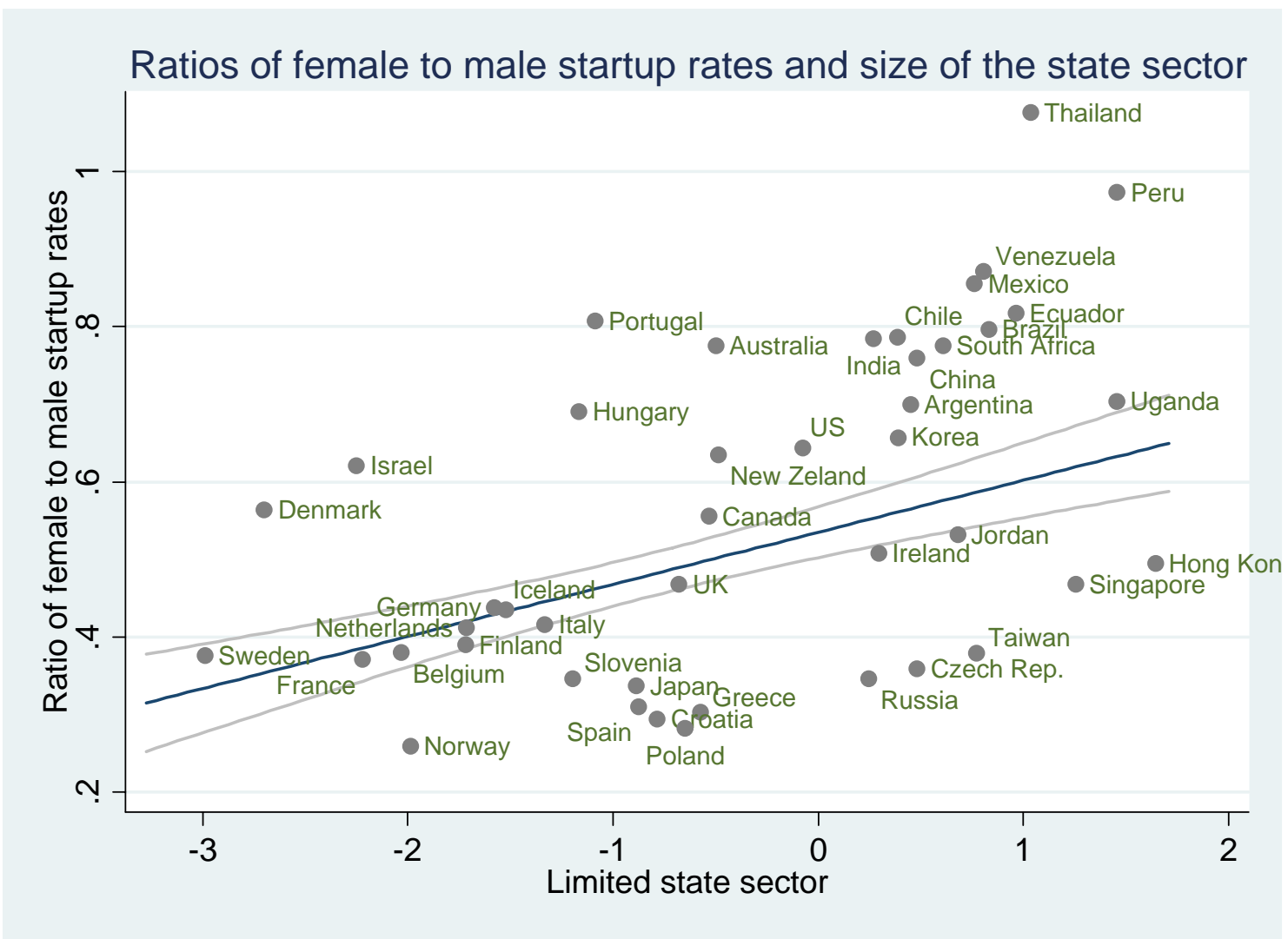


Figure 4.

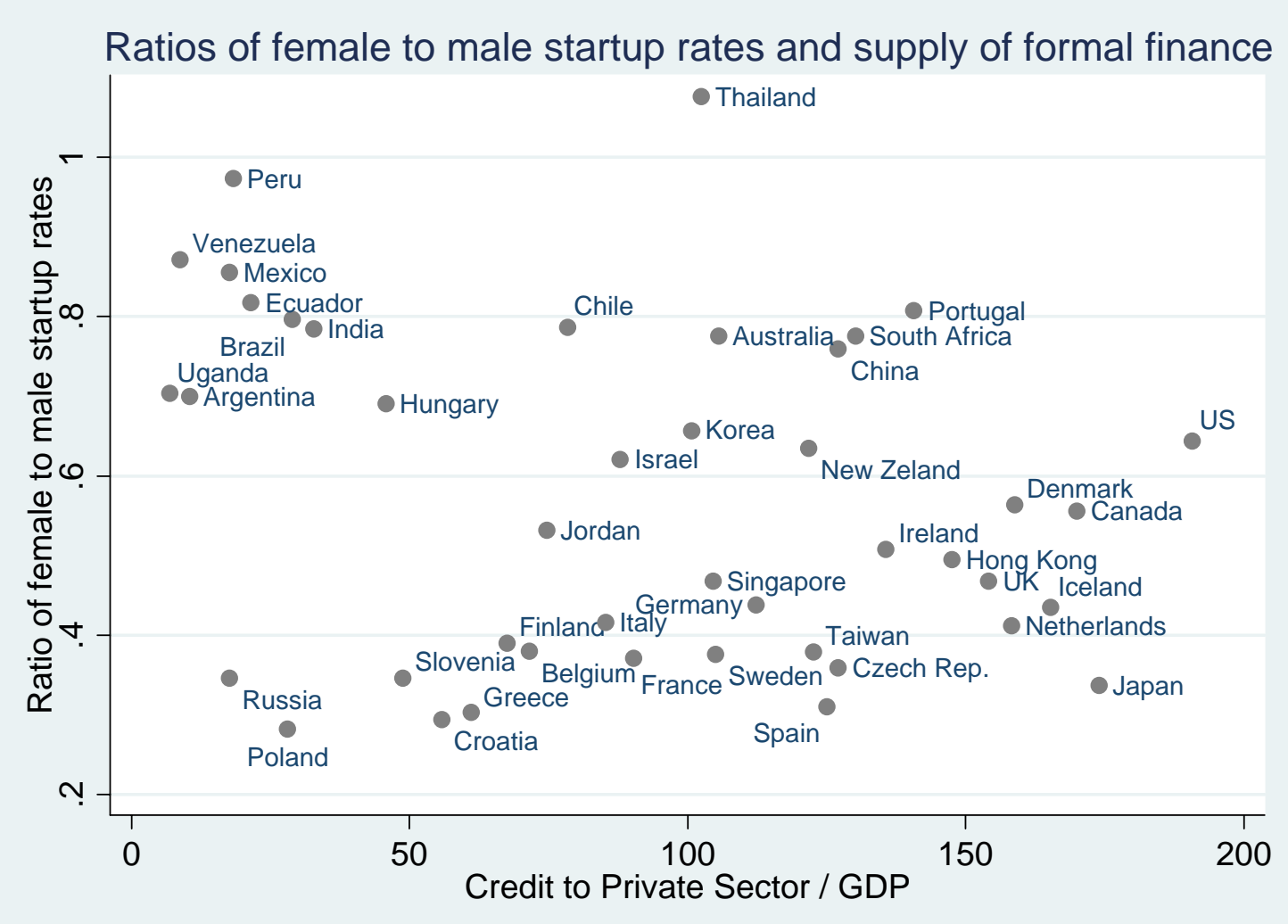


Figure 5.

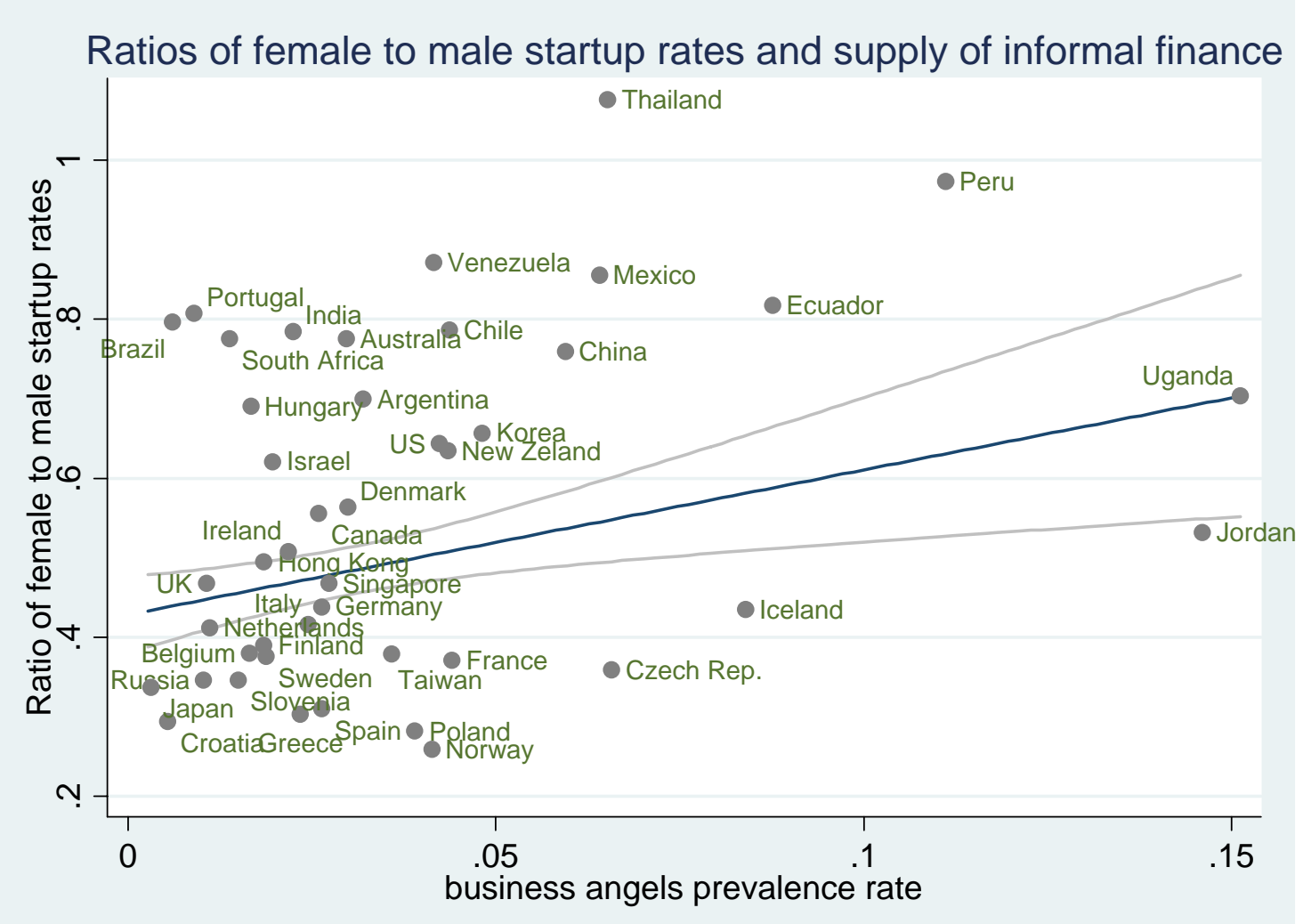




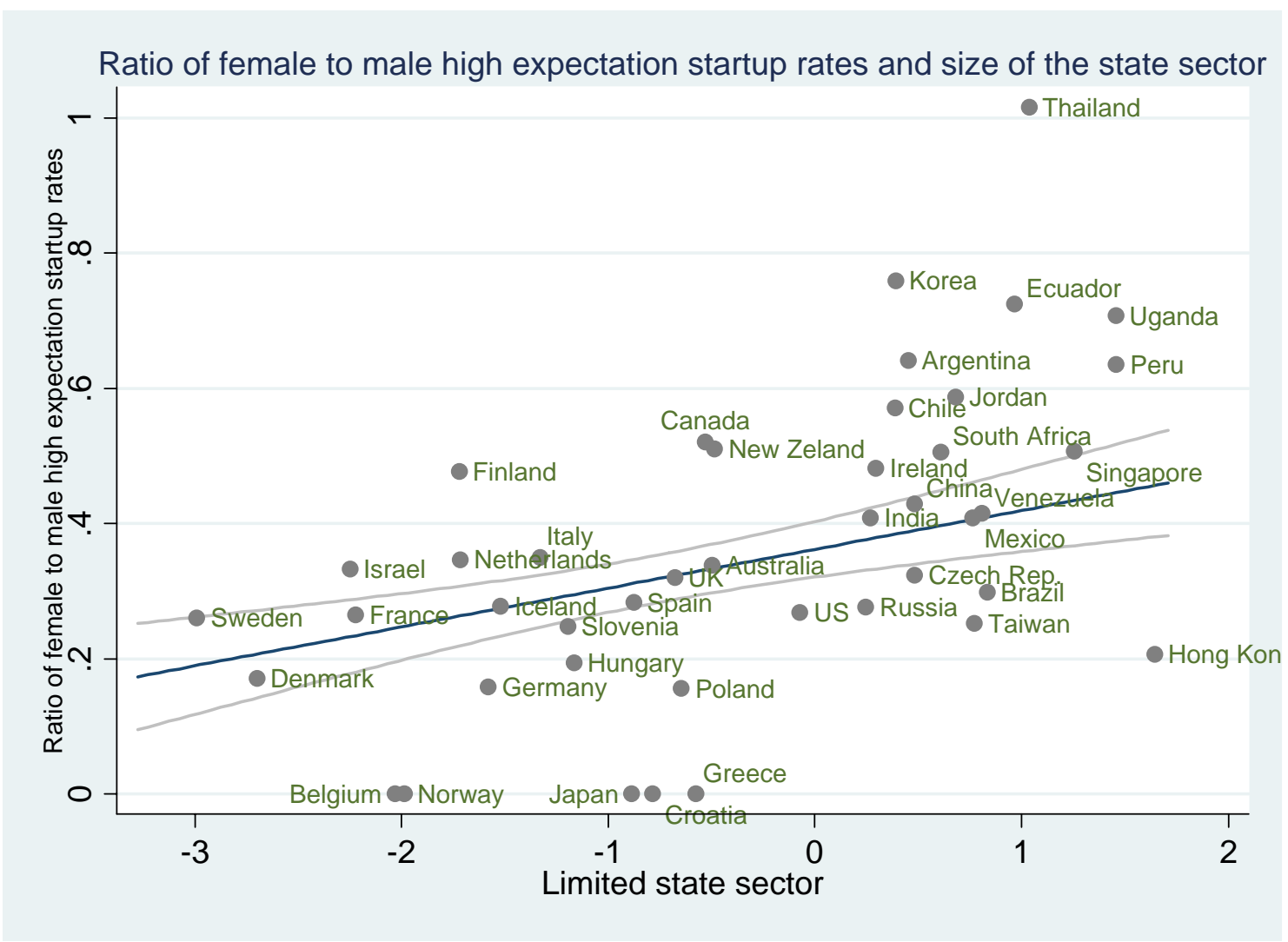




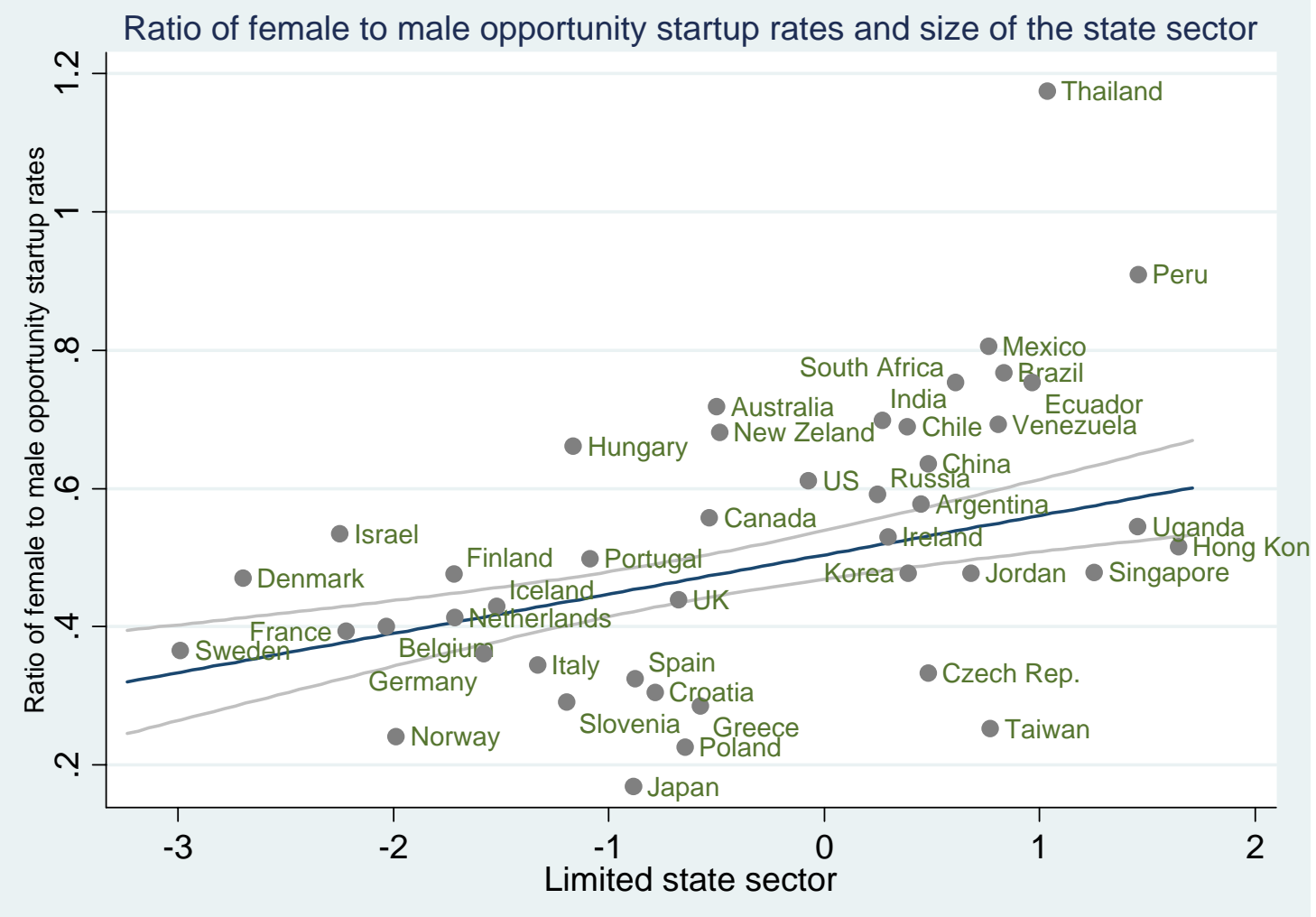

